\title{
Analysis for the Development of a Physical Education Learning Model for Children with Special Needs
}

\author{
Sumaryanti \\ Faculty of Sport Sciences \\ Universitas Negeri Yogyakarta \\ Yogyakarta, Indonesia \\ sumaryanti@uny.ac.id \\ Bernadeta Suhartini \\ Faculty of Sport Sciences \\ Universitas Negeri Yogyakarta \\ Yogyakarta, Indonesia \\ suhartini@uny.ac.id
}

\author{
Margono \\ Faculty of Sport Sciences \\ Universitas Negeri Yogyakarta \\ Yogyakarta, Indonesia \\ margono@uny.ac.id \\ Dapan \\ Faculty of Sport Sciences \\ Universitas Negeri Yogyakarta \\ Yogyakarta, Indonesia \\ dapan@uny.ac.id
}

\begin{abstract}
-despite the implementation of the newest curriculum recommended by the government, physical education (PE) teachers at special schools still encounter difficulties in the effective and efficient management of the instructional process. This is due to the students' heterogeneity and their low level of physical fitness. Thus, it is quintessential to investigate the need level of PE teachers. This research aimed to investigate the need level of educational subjects, namely teachers and students, towards the development of a PE learning model for physical fitness. A descriptive research method (which involved the use of direct observation and questionnaire) was used to elucidate the findings generated in this study. The participants included $34 \mathrm{PE}$ teachers and 60 students at a special school. The data were analyzed using descriptive percentage. The results showed that $87 \%$ of the students agreed to the development of a learning model. This finding was strengthened by the $100 \%$ agreement of the PE teachers on the learning model, which can improve students' activity during PE instructional process. Therefore, the need level of PE teachers and students at a special school in Yogyakarta, towards the development of a PE learning model on physical fitness is very high.
\end{abstract} fitness

Keywords—need, physical education learning model, physical

\section{INTRODUCTION}

The advancement in technology and globalization has impacted the education system in different parts of the world. This era has forced the government to develop some aspects of education in Indonesia, these include the development of instructional processes, assessment models, facilities and infrastructure.

The Indonesian government, through the Regulation of the Minister of Education and Culture, No. 22 of 2016, explains the need to develop the instructional process and learning model that enable students to be active, creative, and innovative in order to provide a meaningful learning experience. In addition, there is a need for curriculum reformation at each level of education. The impact of this reformation is a major issue of concern to educational practitioners, especially teachers and students. Physical education (PE) is a subject that demands students to be active, creative, and innovative in solving the problems encountered during physical activities. It also requires the teachers to be creative and innovative in the development of an effective learning model in a special school. In the Yogyakarta Special Region, the newest PE curriculum proposed by the government has been implemented. However, the difficulties associated with the management of efficient and effective instructions remained a major issue. It is therefore important to investigate the need level for the development of an effective PE learning model on physical fitness subject-matter in a special school.

One of the important goals of physical education is to systematically and continually improve active lifestyle, in order to maintain the physical fitness of students [1] at a special school. Physical fitness can be described as a series of characteristics associated with health or skills related to the efficient performance of physical exercises or daily activities [2]. The fitness components related to health include cardiorespiratory fitness, muscular fitness, flexibility, and body composition [3], while the components related to physical skills include agility, balance, coordination, power, time reaction, and speed [4].

Physical education model or design with game-based physical activities that are well-structured and applied continually can improve physical fitness (including healthrelated fitness and skill-related fitness) in individuals [5]. The use of a project-based learning (PBL) model increases the students' knowledge of health-related fitness (HRF) [6,7]. Based on the data collected through direct observation and interviews with some teachers at special schools, it can be inferred that there is a need to change the mindset about teaching strategies. Most teachers still encounter difficulties in changing the habit of using demonstration or providing examples on certain moves that need to be performed by students during physical activities. They need to explore the 
new habit of giving the students stimuli to solve the problems encountered while performing certain physical activities, as suggested by the Regulation of the Minister of Education and Culture, No. 22 of 2016.

Thus, some researchers have conducted a preliminary study (in the form of a need-analysis study) on the development of a PE learning model, especially on physical fitness subject-matter for children with special needs. This research, however, aimed to investigate the need level of educational subjects, namely teachers and students, towards the development of a PE learning model for physical fitness.

\section{METHOD}

A descriptive research method was used to elucidate the findings generated in this study. The participants of this research study include $34 \mathrm{PE}$ teachers and 60 students at special schools. A combination of direct observation and questionnaire techniques were used to obtain data. The data were then analyzed using the descriptive percentage method.

\section{FINDINGS AND DISCUSSION}

The result of the study conducted to investigate the need for the development of a PE learning model on physical fitness subject-matter at a special school in Yogyakarta Special Region is divided into two parts: students' needs and teachers' needs. The result of the analysis of students' needs is presented in Table 1, while that of teachers' needs is shown in Table 2.

TABLE I. THE RESULT OF THE ANALYSIS OF STUDENTS' NEED FOR THE DEVELOPMENT OF A PE LEARNING MODEL

\begin{tabular}{|c|c|}
\hline Scale & $\begin{array}{c}\text { PE learning model which enables students } \\
\text { to be active }\end{array}$ \\
\hline Strongly Disagree & $0 \%$ \\
\hline Disagree & $13 \%$ \\
\hline Agree & $21 \%$ \\
\hline Strongly Agree & $66 \%$ \\
\hline
\end{tabular}

Table 1 shows that $87 \%$ of the students, which comprises those who agreed and strongly agreed, need the development of a PE learning model on physical fitness.

TABle 2: The Result of the ANALysis of TeACHERS' NeEd FOR THE DEVELOPMENT OF A PE LEARNING MODEL

\begin{tabular}{|c|c|c|c|}
\hline Scale & $\begin{array}{c}\text { Learning } \\
\text { Process }\end{array}$ & $\begin{array}{l}\text { Learning } \\
\text { Instrument }\end{array}$ & $\begin{array}{c}\text { Teachers' Need of } \\
\text { Learning Model }\end{array}$ \\
\hline Strongly Disagree & $0 \%$ & $0 \%$ & $0 \%$ \\
\hline Disagree & $0 \%$ & $0 \%$ & $0 \%$ \\
\hline Agree & $63 \%$ & $39 \%$ & $0 \%$ \\
\hline Strongly Agree & $37 \%$ & $61 \%$ & $100 \%$ \\
\hline
\end{tabular}

Table 2 shows that $100 \%$ of teachers (which comprises those who agreed and strongly agreed) need an active learning process, good learning instrument, and a learning model on physical fitness subject-matter that is fun and effective towards the achievement of the expected learning outcome. However, there is no appropriate learning model, because the smoothness of a learning process depends on the students' condition, the characteristics of learning materials, and the availability of learning facilities and media, as well as the teachers 'condition [8].

\section{CONCLUSION}

The findings generated in this study showed that there is a need, for the development of a learning model on physical fitness subject-matter that is fun and able to improve the level of students' activities. Furthermore, it is quintessential to conduct an advanced research on how the learning model can be developed to help students and teachers at special schools to achieve the expected learning outcome.

\section{ACKNOWLEDGMENT}

This work was supported by the Faculty of Sport Sciences of Yogyakarta State University and the Department of Education and Sport at Yogyakarta Special Region.

\section{REFERENCES}

[1] Judith E. Rink, Tina J. Hal. Research on Effective Teaching in Elementary School Physical Education. Elementary School Journal. 2008. $108 \quad$ (3) 207 218.http://www.journals.uchicago.edu/toc/esj/curren

[2] J. Jarani, A. Grøntved, F. Muca, A. Spahi, D. Qefalia, K. Ushtelenca, A. Kasa, D. Caporossi \& M. C. Gallotta. Effects of two physical education programmes on health- and skill-related physical fitness of Albanian children. Journal of Sports Sciences, 2016. 34, Issue 1

[3] Xiangli Gu , Mei Chang, Melinda A. Solmon. Physical Activity, Physical Fitness, and Health-Related Quality of Life in School-Aged Children. Journal of Teaching in Physical Education. 2016. 36 (2).

[4] Maria Chiara Gallotta, Gian Pietro Emerenziani, Sara Iazzoni, Luigi Iasevoli, Laura Guidetti \& Carlo Baldari.Effects of different physical education programmes on children's skill- and health-related outcomes: a pilot randomised controlled trial. Journal of Sports Sciences, 2017. 35, Issue 15

[5] Narelle Eather, Philip James Morgan \& David Revalds Lubans. Improving health-related fitness in adolescents: the CrossFit Teens ${ }^{\mathrm{TM}}$ randomised controlled trial. Journal of Sports Sciences, 2016. 34, Issue 3

[6] Peter A. Hastie, Senlin Chen , Anthony J. Guarino. Health-Related Fitness Knowledge Development Through Project-Based Learning. Journal of Teaching in Physical Education. 2017. 36 (1).

[7] J. Houston, \& Kulinna. Health-related fitness models in physical education. Strategies. 2014. 27, 20-26.

[8] Ronald A. Berk. Survey of 12 Strategies to Measure Teaching Effectiveness. International Journal of Teaching and Learning. 2005. $17(1), 48-62$ 